\title{
SOBRE O PROCESSO DE INSTALAÇÃO DO \\ GRUPO ESCOLAR DE ARAGUARI, MG
}

Apresentação

Araguari, MG, é um município mineiro desde 19/10/1882, e se localiza na região do Triângulo Mineiro, próxima de Uberlândia, MG, em $34 \mathrm{~km}$. O Grupo Escolar de Araguari, assim era a sua denominação inicial, foi criado em 17/11/1908, e cinco meses depois, em 17/04/1909 foi instalado. Em termos regionais, esse grupo escolar foi o segundo a se efetivar em termos de instalação, em seguida à do grupo escolar da cidade de Prata, MG, ocorrida em 18/09/1908.

Ato legislativo de criação: Decreto n. 2.297, de 17 de novembro de 1908:

Créa o grupo escolar da cidade de Araguary

O Vice Presidente do Estado de Minas Geraes, de conformidade com o disposto no art. 22, combinado com o artigo 45 do regulamento que baixou com o dec. n. 1960, de 16 de dezembro de 1906, considerando que é necessária a diffusão do ensino público primário, de acordo com os novos methodos adoptados, resolve, para execção do disposto no art. da lei n. 439, de 28 de setembro daquelle anno, crear o grupo escolar da cidade de Araguary.

Palacio da Presidencia do Estado de Minas Geraes, em Bello Horizonte, 17 de novembro de 1908.

Julio Bueno Brandão

Estevão Leite de Magalhães Pinto.

O processo de instalação e de toda a movimentação política em torno da mesma pode ser aquilatado, conforme relato de Mário da Silva Pereira, advogado e responsável pela referida instalação, bem como primeiro diretor do grupo escolar.

Trata-se de uma carta escrita, em 1959, à então Diretora do Grupo Escolar Raul Soares - denominação que substitui Grupo Escolar de Araguari -, Maria de Lima Alessi, conforme solicitação desta, certamente em vista da preservação da memória e da história do referido Grupo Escolar.

Sua relevância pode ser aquilatada pelo próprio leitor, uma vez que o primeiro diretor assume o processo de instalação do referido Grupo Escolar em dezembro de 1908, logo após a sua criação, e permanece em sua direção até agosto de 1910.

José Carlos Souza Araujo 
Eis a íntegra da carta ${ }^{1}$ :

\author{
MARIO DA SILVA PEREIRA \\ ADVOGADO \\ AV. AMAZONAS 1306 \\ BELO HORIZONTE
}

Exma. Sra.

Maria de Lima Alessi

MD. Diretora do Grupo Escolar "Raul Soares"

Araguari - Minas Gerais

Minha Senhora

Tenho em mãos sua prezada carta de 26 de abril passado, pedindo informações sôbre a fundação do Grupo Escolar e da sua administração e funcionamento, durante pouco mais de um ano, em que organizei, instalei e dirigi o estabelecimento.

Terminava eu o quinto ano de direito, quando fui convidado pelo Secretário do Interior - Dr. Estevam Leite de Magalhães Pinto, - então meu professor de Economia Política na Faculdade de Direito, que me declarou que, sendo eu formado pela Escola Normal de Arassuaí [MG], vinha pedir-me um favor, o de, antes de entrar como Promotor de Justiça da Primeira Comarca para que seria nomeado, fosse a esta cidade desempenhar uma comissão que êle me dava, que era de organizar e dirigir inicialmente o estabelecimento, nos primeiros dias de seu funcionamento.

O motivo principal que tinha para me encarregar desta comissão era de haver para o Grupo somente o prédio e a indicação de 7 professores que êle não sabia se deviam, de fato, ser nomeados e, além disso, porque os dois candidatos à Diretoria do Grupo, indicados pelos políticos da cidade, lhe pareciam incompetentes para tal incumbência, ficando eu autorizado a indicar novos professores e adquirir o que fosse necessário para o funcionamento do estabelecimento.

Chegando a Araguari, depois de diversos dias de viajem, através de estrada de ferro, fui festivamente recebido pela população local que fazia uma idéia exagerada da importância do estabelecimento, adquirindo, assim, desde logo, conhecimentos e relações pessoais de várias pessôas do município.

Fui, realmente, auxiliado por diversos elementos da sociedade, uns, políticos, outros, alhêios à política local, para conseguir orientação a fím de poder montar o estabelecimento, como eu sabia dever ser necessário.

Pelas pêssoas indicadas para professores, notei que alguns eram já mestres primários, exercitados nas próprias escolas locais, e que, apesar de serem pouco instruídos em matéria literária e profissional, pertenciam à sociedade local e, no meu juízo, exerciam com consciência o seu trabalho e deveriam ser aproveitados, mesmo porque não havia elementos locais adequados para a função escolar. 
Entre os professores que o Gôverno já havia deliberado nomear, e que me autorizou a excluir, se julgasse necessário, havia os seguintes: uma professora bastante inteligente, que se chamava Beni de Genet Roquete e alguns elementos novos, não experientes, como Gastão Salazar, Miguel José da Costa (indicado para Diretor), Afonso Batista Pinheiro (outro indicado para Diretoria), José Carvalhais Filho, Da. Cecília Costa, Da. Josefina dos Reis Andrade.

Os indicados para Diretor não me pareciam competentes e aptos para êsse cargo e vários professores eram iniciantes na vida escolar.

Tive, portanto, que obter de São Paulo uma candidata competente e já treinada, para completar o número das professoras, e que se chamava, se me lembro, Da. Izabel, e que veiu a se chamar Izabel Salazar, pelo casamento com o Sr. Gastão Salazar, algum tempo depois de minha retirada.

Tive que abrir uma aula para os professores ainda inexperientes, a fim de ensinarlhes o novo método (de palavração) para o ensino da leitura, que constituía novidade da forma da instrução pública no Estado.

Construí, junto ao Grupo, duas cobertas, em dois recrêios contíguos, para abrigo dos alunos na ocasião do intervalo entre as aulas.

Tendo chegado em Araguari em comêço de Dezembro de 1908, consegui preparar o prédio e as suas dependências e inaugurar o Grupo no dia 17 de março de 1909, conforme consta da ata de instalação.

O prédio era constituído de, apenas, quatro salas de aula e dois cômodos menores, um para o Diretor, e outro para o arquivo, de maneira que tive de organizar dois turnos diários, um das 7 às 11 horas, e outro de 13 às 17 horas.

Notei, ao fim do ano, que os professores, que nada sabiam a respeito do ensino primário, tiveram melhor êxito no novo método do que aquêles já viciados pelo sistema antrior e que tinham algum conhecimento do ensino elementar, pois, o resultado em cada uma dessas aulas foi muito diferente, e melhor nas salas onde funcionavam professores absolutamente sem tirocínio e que procurei ensinar no novo método.

Já no ano seguinte fiz apenas a matrícula, que foi muito superior à do primeiro ano, e os professores já se achavam mais afeitos ao mister de ensinar.

Retirei-me de Araguari em agôsto de 1910, para ir ocupar cargo de Promotor de Justiça de Mar da Espanha, terra do Dr. Estevam Pinto e que me designou como prêmio pelo serviço prestado na instalação e organização do Grupo Escolar de Araguari.

Recebi do Dr. Estevam Pinto um ofício muito elogioso, pelo trabalho desempenhado, como era de seu conhecimento pelas informações que lhe chegaram às mãos, e pelas referências elogiosas feitas pela imprensa de Araguari e outros municípios.

Não me recordo de quem tenha sido o meu substituto na Diretoria. Sei, apenas, que foi nomeado posteriormente, em caráter efetivo, o Sr. José Felizardo de Almeida.

Daí em diante, o Grupo funcionou à minha completa revelia. Levei de Araguari uma das minhas mais lindas alunas, como minha espôsa, Adelina França, minha primeira mulher.

Não tenho nada mais a informar alem disso sobre o Grupo Escolar. A título de curiosidade, tenho a informar que, dos professores nomeados por indicação minha, os mais novos e menos experientes no ensino foram Gastão Salazar e Cecília Costa, que se tornaram, afinal, os mais eficientes na aplicação do novo método de ensino. 
Para terminar, cumpre-me informar a V. Excia. que era, então, Presidente da Câmara Municipal e Agente Executivo do Município o Cel. Olímpio dos Santos, sendo chefes políticos, sempre atendidos, o Cel. Adalardo Cunha e José Ferreira Alves.

Com minhas excusas pela deficiência das informações desejadas por V. Excia., deficiência essa causada pelo meu estado de saúde e pela idade, que já é avançada, subscrevo-me muito atenciosamente, continuando a seu inteiro dispôr para quaisquer novos esclarecimentos.

O patrício admirador

Mario da Silva Pereira

\footnotetext{
${ }^{1} \mathrm{O}$ referido documento foi extraído da dissertação de Wendell Luiz Pereira, intitulada Grupo Escolar de Araguary a Raul Soares (1945-1961), defendida em 2010 junto ao Programa de Pós-Graduação em Educação da Universidade Federal de Uberlândia.
} 